\title{
Non-destructive chemical sensing within bulk soil using 1000 biosensors per gram of matrix
}

\author{
Emily M. Fulk ${ }^{1}$, Xiaodong Gao², Li Chieh Lu ${ }^{3}$, Kelly R. Redeker ${ }^{4}$, \\ Caroline A. Masiello ${ }^{2,3,5}$, and Jonathan J. Silberg, $3,6,7, *$
}

Author affiliations:

1. Systems, Synthetic, and Physical Biology Graduate Program, Rice University, 6100 Main Street, MS-180, Houston, Texas 77005

2. Department of Earth, Environmental and Planetary Sciences, Rice University, 6100 Main St, MS-126, Houston, TX 77005

3. Department of Biosciences, Rice University, 6100 Main Street, MS-140, Houston, TX, 77005

4. Department of Biology, University of York, Heslington, York, YO10 5DD, United Kingdom

5. Department of Chemistry, Rice University, 6100 Main Street, MS-60, Houston, TX, 77005

6. Department of Bioengineering, Rice University, 6100 Main Street, MS-142, Houston, TX, 77005

7. Department of Chemical and Biomolecular Engineering, Rice University, 6100 Main Street, MS-362, Houston, TX, 77005

* Jonathan J. Silberg, Department of Biosciences, Rice University, 6100 Main Street, MS140, Houston, TX, 77005; Tel: 713-348-3849; Email: joff@rice.edu

KEYWORDS: biosensor, gas reporter, material, microbe, soil, sediment, synthetic biology 


\begin{abstract}
Gene expression can be monitored in hard-to-image environmental materials using gasreporting biosensors, but these outputs have only been applied in autoclaved matrices that are hydrated with rich medium. To better understand the compatibility of indicator gas reporting with environmental samples, we evaluated how matrix hydration affects the gas signal of an engineered microbe added to a sieved soil. A gas-reporting microbe presented a gas signal in a forest soil (Alfisol) when hydrated to an environmentallyrelevant osmotic pressure. When the gas signal was concentrated prior to analysis, a biosensor titer of $10^{3}$ cells/gram soil produced a significant signal when soil was supplemented with halides. A signal was also observed without halide amendment, but a higher cell titer ( $10^{6}$ cells/gram soil) was required. A sugar-regulated gas biosensor was able to report with a similar level of sensitivity when added to an unsterilized soil matrix, illustrating how gas concentration enables biosensing within a soil containing environmental microbes. These results establish conditions where engineered microbes can report on gene expression in living environmental matrices with minimal perturbation, using biosensor titers that are orders of magnitude lower than the number of cells typically observed in a gram of soil.
\end{abstract}




\section{INTRODUCTION}

Soil microbes live within spatially and temporally heterogeneous environments, where macroscale environmental properties, including climate and land management practices, can significantly alter microscale conditions ${ }^{1,2}$. The soil microbiome is responsible for many critical processes, such as controlling the formation and turnover of soil organic carbon, regulating nitrogen cycling, producing greenhouse gases, and forming essential plant symbioses ${ }^{1-3}$. However, the connection between macroscale environmental conditions, the microscale environment, and microbial behavior remains poorly understood ${ }^{1-4}$. Engineered microbes that function as biosensors provide a strategy to study how individual microbes respond to dynamically changing conditions in bulk environmental matrices like soils and sediments ${ }^{4}$. While early biosensors relied on fluorescent or ice nucleation protein outputs to monitor gene expression, these reporters require applications of high biosensor titers, sample processing, and extraction from matrices to enable quantification of the output signal ${ }^{4-7}$.

Volatile gas reporters of gene expression offer an opportunity to non-destructively monitor microbial behaviors in bulk matrices with minimal sample processing ${ }^{4}$. To date, methyl halides ${ }^{8}$, acetaldehyde $e^{9,10}$, hydrogen sulfide ${ }^{11}$, ethylene ${ }^{12}$, and methyl salicylate ${ }^{13}$ have all been leveraged as gas reporter outputs. Among these outputs, methyl halides have been used to the greatest extent in matrices. These outputs are generated by programming cells to conditionally express a methyl halide transferase $(\mathrm{MHT})^{8}$, which catalyzes the production of $\mathrm{CH}_{3} \mathrm{Cl}, \mathrm{CH}_{3} \mathrm{Br}$, or $\mathrm{CH}_{3} \mathrm{I}$ from halide ions and S-adenosyl methionine ${ }^{14}$. When used as a metabolic output for biosensors, these chemicals can diffuse through soil matrices to the headspace of closed systems and be quantified using 
gas chromatography-mass spectroscopy (GC-MS) without disrupting the matrix. MHT reporters can produce a signal under both oxic and anoxic conditions, making them useful in materials containing oxygen gradients ${ }^{8}$. To date, MHT reporters have been used to study gene transfer in soil ${ }^{8}$, the effect of soil on the bioavailability of microbe-microbe signaling molecules ${ }^{12}$, and the effect of organic matter on the bioavailability of a microbeplant signaling compound ${ }^{15}$. Additionally, MHTs have been used in synthetic soils to monitor the effects of different soil properties on the bioavailability of cell-cell signals ${ }^{16}$.

To obtain a robust indicator gas signal from environmental matrices, prior gas reporter studies have all used twice-autoclaved matrices that are hydrated with a nutrientrich growth medium, which leads to osmolarities an order of magnitude above typical levels in the environment ${ }^{8,12,16}$. This growth medium has also been supplemented with halide salts at concentrations that are orders of magnitude higher than the levels found in natural matrices like soils $8,12,16,17$. Furthermore, biosensors have been added at titers that exceed the abundance of individual consortia members ${ }^{18-20}$ and are on par with the total cell population in environmental matrices ${ }^{1,21,22}$. When environmental matrices are modified in these ways, the structure and function of the native microbiome is disrupted, limiting the utility of gas biosensors to monitor native microbial consortia without perturbation ${ }^{16,23-25}$. To use biosensors under conditions that better reflect natural soil environments, there is a need to apply more sensitive detection methods to quantify trace indicator gas signals. To date, gas biosensor studies have used detection methods capable of quantifying $\mathrm{CH}_{3} \mathrm{Br}$ signals above $\sim 1,000 \mathrm{ppt}$ (mol/mol) in the gas phase ${ }^{12}$, which is $>100$-fold higher than natural atmospheric levels $(\sim 7 \mathrm{ppt}, \mathrm{mol} / \mathrm{mol})^{26}$. Gas concentration methods such as thermal desorption (TD) can be coupled with GC-MS to 
measure dynamic $\mathrm{CH}_{3} \mathrm{X}$ fluxes in the environment, but these methods have not yet been used to monitor gas outputs from engineered microbes ${ }^{27-29}$.

To better understand how environmental matrices impact indicator gas signals relative to the ambient background, we evaluated how matrix treatment affects detection of gas biosensor output from an Alfisol forest soil (Oxyaquic Glossudalf). Specifically, we assessed how the composition of the soil hydration medium, signal accumulation time, and matrix sterilization affected the indicator gas signal. We find that Escherichia coli biosensors present a robust signal when introduced into a sieved and homogenized Alfisol that was hydrated to environmentally-relevant osmolarity using nitrogen-limiting minimal growth medium, which reflects famine conditions observed in nature outside of hotspots and hot moments of microbial activity ${ }^{1,2}$. Additionally, we show that a signal can be obtained from a soil using natural halide levels present in the matrix. Amending the Alfisol with halides improves the indicator gas signal 1000-fold and enables detection of a sugar using as few as $10^{3}$ engineered cells/gram soil. This biosensor titer is orders of magnitude lower than both the total number of cells observed in a gram of soil $\left(10^{7}\right.$ to $10^{12}$ cells/gram soil) $)^{1,21,22}$ and the number of cells applied to enable previous gas biosensor studies $\left(\sim 10^{8} \text { cells/gram soil }\right)^{8,12}$. 


\section{RESULTS AND DISCUSSION}

Effect of halide amendments on gas signal. To obtain an environmental matrix for studying the gas reporter signal produced by an engineered microbe, we collected and characterized the A and B horizon of an Alfisol (Oxyaquic Glossudalf) from a forest near the San Jacinto River in Conroe, TX. This site has not experienced any agriculture since at least 1984 . The physical and chemical properties for this soil are summarized in Table 1. This soil is nutrient-poor with a low organic matter content and halide concentrations that are below the estimated global averages for soil chloride (100 ppm), bromide (32 ppm), and iodide $(3.9 \mathrm{ppm})^{17}$. Additional soil characterization included particle size distribution (Table S1), mineralogy (Table S2 and Figure S1), and water retention properties (Figure S2).

Initially, we evaluated the gas signal from an E. coli strain that constitutively expresses an MHT (MG1655- $m h t)^{8}$ within a twice-autoclaved B horizon soil. We hydrated the soil to $32 \%$ field capacity with M63 medium containing $10^{7}$ colony forming units (CFU) per gram of dry soil and a range of $\mathrm{NaCl}$ or $\mathrm{NaBr}$ concentrations (Figure 1a-b). Following a 24-hour incubation, we observed a significant $\mathrm{CH}_{3} \mathrm{Cl}$ signal in soil samples having $\geq 10$ mM supplemental $\mathrm{NaCl}(\mathrm{p}<0.01$, two-sided $t$ test $)$. While the average $\mathrm{CH}_{3} \mathrm{Br}$ signal was higher than the detection limit in the absence of supplemental $\mathrm{NaBr}, \geq 10 \mathrm{mM} \mathrm{NaBr}$ was also required to yield a significant signal ( $p<0.01$, two-sided $t$ test). Negative controls performed using soil augmented with wildtype E. coli MG1655 did not present detectable $\mathrm{CH}_{3} \mathrm{X}$ under any condition tested.

Soils hydrated with minimal growth media, such as M63, exhibit hydrologic properties very different from those in natural soils because the osmotic pressure of 
minimal growth medium is higher than the aqueous phase of soils in situ. One way to overcome this challenge is to hydrate soils with diluted minimal medium, such as MIDV $1^{16}$. To determine how hydration at a more realistic osmotic pressure affects the output from gas-reporting microbes, we evaluated the signal from soils hydrated to $64 \%$ field capacity using MIDV1 containing MG1655-mht (107 CFU/gram soil). In the absence of $\mathrm{NaCl}$ or $\mathrm{NaBr}$ supplementation (Figures 1c-d), we found that indicator gas signals were significantly above the $\mathrm{CH}_{3} \mathrm{X}$ background ( $\mathrm{p}<0.01$, two-sided $t$ test). For both halides, the headspace gas signal increased with the concentration of halides added to soil. A comparison of gas signals from soil hydrated with M63 and MIDV1 medium revealed that the $\mathrm{CH}_{3} \mathrm{Br}$ signal is higher than the $\mathrm{CH}_{3} \mathrm{Cl}$ signal when similar levels of each halide salt are added. This trend is interpreted as arising because the Batis maritima MHT used for this study has a lower $\mathrm{K}_{\mathrm{m}}$ for bromide $(18.5 \mathrm{mM})$ compared to chloride $(155 \mathrm{mM})^{30}$.

In the environment, soil microbes live under conditions that are frequently nutrientlimiting to model synthetic biology chassis, such as $E$. coli ${ }^{31}$. To better understand how growth limitations affect gas production, we incubated MG1655-mht in soil hydrated to $64 \%$ field capacity with low-osmolarity MIDV1 (20 mM NaBr) containing or lacking nitrogen (Figure 2a). Under nitrogen-deficient (-N) conditions, we found that the maximum gas signal was $44 \%$ of that observed in samples containing nitrogen following a 24 -hour incubation. To evaluate how cell titer and supplemental halides affected gas signal under nitrogen-limiting conditions, we quantified the signal from soil containing different titers of MG1655-mht that had been hydrated to the same water content with MIDV1 (-N) containing a range of $\mathrm{NaBr}$ concentrations (Figures 2b, S3). The $\mathrm{CH}_{3} \mathrm{Br}$ signal correlated with both cell titer and supplemental halide concentration following a 24-hour incubation. 
Across the range of conditions tested, both $\mathrm{NaBr}$ concentration and cell titer had similar effects on the $\mathrm{CH}_{3} \mathrm{Br}$ signal, such that an order of magnitude increase in either the cell population or $\mathrm{NaBr}$ concentration increased the gas signal by similar amounts.

Gas signal dynamics in soil. Many soil processes are associated with hot spots and hot moments that occur sporadically in the environment ${ }^{1,2}$ and may fluctuate over timescales (days to seasons) that exceed short incubations (hours to days) typically used for gas biosensors $^{8,12}$. As such, it is important to understand indicator gas persistence over longer timescales. To better understand gas signal persistence, we measured headspace gas accumulation in liquid and soil samples over a one-week incubation.

We first evaluated the $\mathrm{CH}_{3} \mathrm{Br}$ signal persistence in liquid cultures containing MG1655 E. coli that constitutively express MHT. We incubated liquid cultures $\left(10^{6}\right.$ $\mathrm{CFU} / \mathrm{mL}$ ) in $\mathrm{M} 63$ medium (-N; $100 \mathrm{mM} \mathrm{NaBr}$ ) for one week at $37^{\circ} \mathrm{C}$ in a shaking incubator and measured the headspace $\mathrm{CH}_{3} \mathrm{Br}$ that accumulated following different incubation durations (Figure 3a). We also measured $\mathrm{CO}_{2}$ accumulation so that we could compare the indicator gas signal dynamics with respiration and metabolic activity (Figure 3b). In liquid culture, the peak $\mathrm{CH}_{3} \mathrm{Br}$ signal was observed following 1 day of incubation, while the peak $\mathrm{CO}_{2}$ signal was observed after 2 days. The $\mathrm{CH}_{3} \mathrm{Br}$ signal declined following the peak, while the $\mathrm{CO}_{2}$ signal remained relatively constant at later time points. The number of viable cells decreased by approximately three orders of magnitude following one week of incubation (Figure S4). To better understand the mechanism underlying the $\mathrm{CH}_{3} \mathrm{Br}$ decline, we added a $\mathrm{CH}_{3} \mathrm{Br}$ standard to liquid cultures containing or lacking wildtype $E$. coli (Figure S5a). With both measurements, we found that $\mathrm{CH}_{3} \mathrm{Br}$ decreased exponentially at similar rates. These findings suggest that the decline is driven by chemical $\left(\mathrm{OH}^{-}\right.$and 
$\left.\mathrm{Cl}^{-}\right)$substitution of $\mathrm{CH}_{3} \mathrm{Br}$ in the liquid phase ${ }^{32-34}$. No significant difference in cell viability was observed between $E$. coli cultures containing or lacking $\mathrm{CH}_{3} \mathrm{Br}$ (Figure S5b). This latter finding suggests that the amount of $\mathrm{CH}_{3} \mathrm{Br}$ produced by $E$. coli expressing $\mathrm{MHT}$ does not affect cell fitness.

To evaluate whether $\mathrm{CH}_{3} \mathrm{Br}$ persistence is also affected by soil, we evaluated the dynamics of a $\mathrm{CH}_{3} \mathrm{Br}$ signal generated by MG1655-mht (107 CFU/gram soil) in B horizon soil hydrated to $64 \%$ field capacity with MIDV1 medium (-N; $20 \mathrm{mM} \mathrm{NaBr})$. We performed these experiments in soil containing a native soil microbiome and soil subjected to two sequential autoclaving cycles. For these measurements, we monitored total $\mathrm{CH}_{3} \mathrm{Br}$ and $\mathrm{CO}_{2}$ accumulation at $22^{\circ} \mathrm{C}$ each day for a week (Figures 3c-d). The indicator gas signals observed in the autoclaved and untreated soils were similar until day 4. After that time, the matrices containing a soil microbiome presented a $\sim 2$-fold lower $\mathrm{CH}_{3} \mathrm{Br}$ signal, which was not significantly different from the twice-autoclaved soils ( $p>0.05$, two-sided $t$ test). In both samples, the $\mathrm{CO}_{2}$ signal increased after the first day and remained stable thereafter. Taken together, these findings show that indicator gas signals are degraded in environmental matrices containing a microbiome.

To better understand how changes in gas production relate to microbial growth and fitness, we extracted and counted cells from the unsterilized soil at each time point. The number of CFU on agar plates containing an antibiotic selection for MG1655-mht peaked after one day and remained consistent over time (Figure S6). These results suggest that the observed $\mathrm{CH}_{3} \mathrm{Br}$ decline in living soils is primarily driven by increased degradation of the $\mathrm{CH}_{3} \mathrm{Br}$ signal rather than decreased viability of $E$. coli. In addition to 
abiotic degradation, microbial consumption of $\mathrm{CH}_{3} \mathrm{X}$ by methylotrophs has been documented in a wide range of soils as a $\mathrm{CH}_{3} \mathrm{X}$ sink in the environment ${ }^{29,35-37}$.

Effect of sample concentration on the limit of detection. We next sought to quantify how background $\mathrm{CH}_{3} \mathrm{Br}$ production from unsterilized soils was influenced by supplemental halides. To achieve the analytical sensitivity necessary to detect ambient levels of $\mathrm{CH}_{3} \mathrm{Br}$, we implemented a TD system that concentrates headspace gas prior to GC-MS analysis. We performed incubations in $2.8 \mathrm{~L}$ flasks, sampled air from the flask headspace into evacuated $0.5 \mathrm{~L}$ sample canisters, pumped the gas sample from the canisters to a TD system with a sorbent-packed cold trap that collects $\mathrm{CH}_{3} \mathrm{X}$, and analyzed the $\mathrm{CH}_{3} \mathrm{X}$ signal following heat-induced desorption of the trap onto a GC-MS (Figure S7). We compared standard curves generated by TD-GC-MS and GC-MS alone and found that indicator gas concentration using TD increased our sensitivity of detecting $\mathrm{CH}_{3} \mathrm{Br}$ and $\mathrm{CH}_{3} \mathrm{Cl}$ by more than two orders of magnitude (Figures S8a-b). To understand ambient $\mathrm{CH}_{3} \mathrm{X}$ variability in the lab where we performed incubations, we measured $\mathrm{CH}_{3} \mathrm{Br}$ and $\mathrm{CH}_{3} \mathrm{Cl}$ over six months. From June to December 2021, we observed an average of 954 ppt $\mathrm{CH}_{3} \mathrm{Cl}( \pm 147 \mathrm{ppt}, \mathrm{mol} / \mathrm{mol})$ and $26 \mathrm{ppt} \mathrm{CH}_{3} \mathrm{Br}( \pm 8 \mathrm{ppt}, \mathrm{mol} / \mathrm{mol})$ in the lab (Figure S8c-d). These laboratory values are 1.7- to 3.7-fold higher than mole fractions observed in the environment, $\sim 550$ ppt $\mathrm{CH}_{3} \mathrm{Cl}$ and $\sim 7 \mathrm{ppt} \mathrm{CH}_{3} \mathrm{Br}^{26}$, suggesting that the methyl halide background will be lower in natural environments.

To determine whether soil hydration increased $\mathrm{CH}_{3} \mathrm{Br}$ levels above the ambient background, we compared $\mathrm{CH}_{3} \mathrm{Br}$ in the headspace of flasks containing either unsterilized or twice-autoclaved soil from the B horizon of the Alfisol. We hydrated the soil to $64 \%$ field capacity with MIDV1 medium (-N; $100 \mathrm{mM} \mathrm{NaBr})$ and incubated the soil in sealed 
flasks for 48 hours at $22^{\circ} \mathrm{C}$. This incubation time was chosen because it yielded the maximum signal in week-long incubations. Both soil samples presented a significant $\mathrm{CH}_{3} \mathrm{Br}$ signal ( $\mathrm{p}<0.01$, two-sided $t$ test) compared to ambient levels (Figure $4 a$ ). Furthermore, over this short time scale, the living soil accumulated significantly more $\mathrm{CH}_{3} \mathrm{Br}$ than the autoclaved soils. Other studies have observed that sterilization treatments significantly alter net $\mathrm{CH}_{3} \mathrm{X}$ flux from soils, affirming that biological processes dominate $\mathrm{CH}_{3} \mathrm{X}$ fluxes in situ $29,38-40$.

We next sought to determine the effect of $\mathrm{NaBr}$ supplementation on soil production of $\mathrm{CH}_{3} \mathrm{Br}$, since the Alfisol being used for microbial incubations contains naturally low bromide levels. To do this, we incubated unsterilized B horizon soil hydrated to $64 \%$ field capacity with MIDV1 medium (-N) that contained a range of $\mathrm{NaBr}$ concentrations. After 48 hours at $22^{\circ} \mathrm{C}$ in the absence of a gas-reporting microbe, all samples presented significantly higher $\mathrm{CH}_{3} \mathrm{Br}$ levels than the ambient background ( $p<0.01$, two-sided $t$ test) (Figure $4 \mathrm{~b}$ ). $\mathrm{CH}_{3} \mathrm{Br}$ accumulation also increased with increasing halide supplementation, indicating that halide availability is a limiting factor for background $\mathrm{CH}_{3} \mathrm{Br}$ production in these soils.

To determine how many gas-producing cells are required to present a signal above the soil background, we hydrated the unsterilized B horizon soil to $64 \%$ field capacity with MIDV1 (-N) containing or lacking NaBr (Figure 4c-d). When supplemented with $20 \mathrm{mM}$ $\mathrm{NaBr}, 10^{3} \mathrm{CFU} /$ gram soil of MG1655-mht was sufficient to produce a signal that was higher than the soil background ( $p=0.001$, two-sided $t$ test). In the absence of halide supplementation, $10^{6} \mathrm{CFU} / g$ ram soil was required to produce a significant signal $(p=$ 0.01, two-sided $t$ test). Taken together, these results show that halide concentration 
affects the magnitude of both the background $\mathrm{CH}_{3} \mathrm{X}$ produced by the soil and the signal produced by engineered cells added to the soil.

Sensing a sugar in living soil. Our results with microbes that constitutively produce an indicator gas suggested that biosensing cells may be able to report on chemicals when present at similar low titers in a living soil. To test this idea, we evaluated the gas signal from MG1655 cells containing an MHT gene whose expression is regulated by the lac repressor (MG1655-IPTG) ${ }^{41}$. In this strain, MHT expression and $\mathrm{CH}_{3} \mathrm{X}$ biosynthesis is induced by isopropyl ß-D-1-thiogalactopyranoside (IPTG). To first investigate whether soil affects IPTG bioavailability, we added MG1655-IPTG (10 CFU/gram soil) to GC vials containing or lacking unsterilized B horizon soil that was hydrated to $64 \%$ field capacity with MIDV1 (-N; $20 \mathrm{mM} \mathrm{NaBr)} \mathrm{containing} \mathrm{varying} \mathrm{IPTG} \mathrm{concentrations.} \mathrm{We} \mathrm{incubated} \mathrm{the}$ samples at $22^{\circ} \mathrm{C}$ for 24 hours before analyzing the headspace gas (Figure 5a). The dynamic range of IPTG sensitivity was similar in liquid and soil incubations, demonstrating that IPTG exhibits high bioavailability in the soil. To benchmark the gas output from the IPTG biosensor to MG1655-mht, we compared the $\mathrm{CH}_{3} \mathrm{Br}$ signal from soil samples containing similar titers $\left(10^{8} \mathrm{CFU} /\right.$ gram soil) of each strain. We performed these experiments in unsterilized B horizon soil hydrated to $64 \%$ field capacity with MIDV1 (-N; $100 \mathrm{mM} \mathrm{NaBr}$ ) containing or lacking IPTG. After a 24-hour incubation at $22^{\circ} \mathrm{C}$, MG1655IPTG produced 2-fold more $\mathrm{CH}_{3} \mathrm{Br}$ in the presence of IPTG compared to MG1655-mht (Figure 5b). MG1655-IPTG also presented a $\mathrm{CH}_{3} \mathrm{Br}$ signal in the absence of IPTG, although IPTG addition increased the signal by 116 -fold in the soil headspace.

To investigate if the IPTG sensor could produce a detectable signal in a living soil when present at the lowest titer where MG1655-mht presented a signal, we added 
MG1655-IPTG at a titer of $10^{3} \mathrm{CFU/gram} \mathrm{soil} \mathrm{and} \mathrm{hydrated} \mathrm{untreated} \mathrm{B} \mathrm{horizon} \mathrm{soil} \mathrm{to}$ 64\% field capacity with MIDV1 (-N; 100 mM NaBr) containing or lacking IPTG (Figure 5c). After 48 hours of incubation at $22^{\circ} \mathrm{C}$, samples containing IPTG presented a 7 -fold higher $\mathrm{CH}_{3} \mathrm{Br}$ signal than samples lacking IPTG, and the signal with IPTG was significantly higher than without IPTG ( $p=0.045$, two-sided $t$ test). $\mathrm{CH}_{3} \mathrm{Br}$ production in the absence of IPTG was not significantly different from background soil production $(p=0.83$, twosided $t$ test).

Implications. Our results demonstrate that non-invasive biosensing with minimal perturbation of the environmental matrix can be achieved with cell titers as low as $10^{3}$ cells/gram soil. Additionally, biosensing at this titer was accomplished in a soil containing an environmental microbiome. The net indicator gas signal presented by a microbe expressing an MHT depends upon many parameters including engineered cell titer, soil halide concentration, and nutrient availability. While a gas signal from biosensing cells could be obtained from a living Alfisol without adding halides, the number of cells required to observe a signal above laboratory background was sensitive to halide supplementation. The cell titers required in the presence and absence of halide supplementation, $10^{3}$ and $10^{6}$ cells/gram soil respectively, are both smaller than the titer of cells $\left(10^{7}\right.$ to $10^{12}$ cells/gram soil) observed in soil microbiomes ${ }^{1,21,22}$. As the soil analyzed in this study has low halide concentrations, soils with higher halides may require fewer biosensors to yield a signal in the absence of halide supplementation. The low limit of detection achieved using TD-GC-MS suggests that indicator gas reporting could be used to monitor the gene expression of native and engineered cells present in hard-to- 
image materials, ranging from microbiome-containing environmental matrices like soils, sediments, and wastewater to synthetic living materials.

The limit of detection for gas-reporting biosensors is expected to vary across materials, and future applications of these biosensors should always include control measurements to establish the background methyl halide levels in each matrix. In our Alfisol incubations, hydrated soils were net sources for $\mathrm{CH}_{3} \mathrm{Br}$ following a two-day incubation. This gas production is interpreted as primarily arising from fungal methyltransferase activity induced by hydrating the soil with medium containing unnaturally high concentrations of halides ${ }^{29,42,43}$. While this background can be minimized by decreasing the halide supplementation, decreasing the halides also attenuates the signal produced by the engineered microbes. The application of gas biosensors in other materials that present background methyl halides, including marine ${ }^{44,45}$ and lacustrine $e^{46,47}$ sediments and samples containing vegetation ${ }^{48,49}$, will also require control measurements to account for natural $\mathrm{CH}_{3} \mathrm{X}$ fluxes.

Our results also demonstrate that the limit of detection for gas biosensors depends upon the incubation duration. This variation arises because methyl halide production and consumption processes vary dynamically in the matrix. When soil was inoculated with engineered cells and incubated for a week, the $\mathrm{CH}_{3} \mathrm{X}$ signal showed a greater decline in unsterilized soils compared to autoclaved soils. We interpret this trend as arising from bacterial degradation, which has been suggested as a major sink for methyl halides in soils $29,35-37$. Abiotic degradation processes including hydrolysis and nucleophilic substitution can also decrease indicator gas signals ${ }^{32-34}$, the latter of which may be particularly important when gas biosensors are deployed in high salinity environments. 
Abiotic methyl halide production in soils with high organic matter content has also been observed $^{29,50}$, indicating that both microbiome and matrix effects are important for determining net methyl halide accumulation over time. Further studies will be needed to elucidate how environmental parameters influence indicator gas signals across different environmental materials, microbiomes, and time scales.

Indicator gas biosensor outputs are expected to be matrix- and treatmentdependent. As such, the optimal supplementation and hydration to maximize the signalto-noise ratio for gas biosensors will vary in each environmental matrix. The soils used in this study have halide concentrations that are more than one order of magnitude below the estimated global averages ${ }^{17}$, suggesting that other matrices may not require supplemental halides for high indicator gas production. Soils with naturally elevated halides that experience moisture regimes favorable to microbial activity are expected to present robust indicator gas production when gas biosensors are introduced into those soils. For example, coastal agricultural soils often have high salinity because they experience rainfall of marine origin with a high salt aerosol content and because seawater can intrude into the ground water ${ }^{51}$. Water content and soil texture will also affect indicator gas signal by impacting biosensor viability and gas diffusion. Under extreme dry conditions, microbial metabolic activity is expected to be attenuated, thereby decreasing indicator gas production rates, while water saturated conditions are expected to hamper gas diffusion from soil pores to the headspace ${ }^{52}$. Natural $\mathrm{CH}_{3} \mathrm{X}$ fluxes in soils are also known to vary with temperature ${ }^{40,53}$, hydration ${ }^{48,54}$, organic matter content ${ }^{29,50}$, halide concentration $^{17}$, redox properties ${ }^{39,54}$ and microbiome ${ }^{29,40}$. Additional studies are needed 
to understand how these processes affect total indicator gas accumulation in the headspace of different matrices.

In future studies, several approaches could be used to improve the signal-to-noise ratio when applying indicator gas reporters in low-halide environmental materials like the Alfisol used here. MHT mutants with greater affinity for halide ions could be developed to improve gas reporting in low-halide environments by increasing the signal from engineered cells under conditions that minimize background. Selections have been reported for methyl transferases that could be applied to identify MHTs with improved substrate affinities ${ }^{55}$. Deep sequencing a library of $\mathrm{MHT}$ mutants before and after selection ${ }^{56}$ could identify mutations that improve cellular fitness in low halide growth conditions. Additionally, gas biosensor signals could be better differentiated from environmental background by combining gas concentration with ${ }^{13} \mathrm{C}$ labelling of biosensor cells and using isotope ratio mass spectrometry to enable detection of trace methyl halide isotopologue abundances ${ }^{29}$. Finally, genetic circuits encoding gas reporters could be transferred into native cellular chassis to reduce the impact of non-native inoculants on soil microbiome structure and decrease the need for supplemental nutrients that may alter matrix processes ${ }^{23-25}$. We expect that these advancements, combined with the ultrasensitive detection described here, will facilitate gas-reporting biosensing in a wide variety of environmental and synthetic matrices. 


\section{METHODS}

Materials. Chloramphenicol was from MilliporeSigma, liquid methyl halide standards were from Restek, and gas-phase methyl halide standards were from Airgas. IPTG was from Research Products International, sodium halides used to create ion chromatography standard curves were from MilliporeSigma, and all other chemicals were from VWR, MilliporeSigma, Fisher, Restek, Apex Biosciences, Research Products International, or BD Biosciences. Enzymes and reagents for molecular biology were from New England Biolabs and Qiagen. Gas tight vials $(2 \mathrm{~mL})$ were from Phenomenex, and gas sample canisters were from LabCommerce.

Strains and plasmids. Table S3 lists the plasmids and strains used in this study. MHT was constitutively expressed in MG1655 using a previously described strain (MG1655$m h t$ ) that expresses Batis maritima $\mathrm{MHT}$ from the chromosome ${ }^{8}$ or $\mathrm{MG} 1655$ transformed with a plasmid ( $p E M F 051$ ) that uses a strong constitutive promoter ${ }^{57}$ to express a fusion of sfGFP ${ }^{58}$ and $\mathrm{MHT}^{8}$ genes linked via (GGGGS)2. MHT was conditionally expressed in MG1655 transformed with a plasmid (pLC7) that regulates expression of MHT using a promoter regulated by the lac repressor $(\mathrm{Lacl})^{41}$. All plasmids were generated using Golden Gate cloning ${ }^{59}$ and sequence verified. pLC7 and pEMF051 contain a chloramphenicol resistance marker and the ColE1 origin. All molecular biology was performed using E. coli XL1-Blue.

Microbial growth. For cloning and strain maintenance, cells were grown in Lysogeny Broth (LB) at $37^{\circ} \mathrm{C}$. Studies analyzing $\mathrm{CH}_{3} \mathrm{X}$ production in liquid culture used a modified M63 medium ${ }^{8}(\mathrm{pH}=7.0)$ containing $1 \mathrm{mM}$ magnesium sulfate, $0.2 \% \mathrm{w} / \mathrm{w}$ glucose, $0.00005 \% \mathrm{w} / \mathrm{w}$ thiamine, $0.05 \% \mathrm{w} / \mathrm{w}$ casamino acids, $20 \% \mathrm{w} / \mathrm{w}$ M63 salt stock, and the 
indicated concentrations of $\mathrm{NaCl}$ or $\mathrm{NaBr}$. Experiments in low-osmolarity medium used modified MIDV1 medium ${ }^{16}(\mathrm{pH}=7.0)$, which contained $1 \mathrm{mM}$ magnesium sulfate, $0.2 \%$ $\mathrm{w} / \mathrm{w}$ glucose, $0.00005 \% \mathrm{w} / \mathrm{w}$ thiamine, $0.05 \% \mathrm{w} / \mathrm{w}$ casamino acids, $0.0125 \% \mathrm{w} / \mathrm{w} \mathrm{M} 63$ salt stock, and the indicated concentrations of $\mathrm{NaCl}$ or $\mathrm{NaBr}$. The $\mathrm{M} 63$ salt stock contained $75 \mathrm{mM}$ ammonium sulfate, $0.5 \mathrm{M}$ monobasic potassium phosphate, and $10 \mu \mathrm{M}$ ferrous sulfate ${ }^{12}$. N-deficient media lacked ammonium sulfate and casamino acids. The optical density of cultures at $600 \mathrm{~nm}\left(\mathrm{OD}_{600}\right)$ was monitored using a spectrophotometer (DS-11, DeNovix). To calibrate OD 600 with cell titer, MG1655 cultures of varying OD600 were incubated overnight on LB-agar plates, and the resulting colonies were counted.

GC-MS analysis. For headspace gas analysis without sample concentration, samples (soil and liquid culture) were added to $2 \mathrm{~mL}$ gas-tight vials (AR0-37L0-13, Phenomenex) and crimped with VEREX tops (AR0-5710-13, Phenomenex). After incubation, headspace gas was quantified using an Agilent 7820 GC connected to an Agilent 5977E MS or an Agilent 8890 GC connected to an Agilent 5977B MS, both with autosamplers (7693A, Agilent). Both systems contained a DB-VRX capillary column (20 m, $0.18 \mathrm{~mm}$ ID, $1 \mu \mathrm{m}$ film; Agilent) and a $100 \mu \mathrm{L}$ gastight syringe (G4513-80222, Agilent) for sampling. The Agilent 7820 GC used a 50:1 split ratio for headspace gas injections (50 $\mu \mathrm{L})$, a column flow of $0.9 \mathrm{~mL}$, and an oven program that held at $45^{\circ} \mathrm{C}$ for $1.3 \mathrm{~min}$. The Agilent 8890 GC used a 55:1 split ratio for headspace gas injection (50 $\mu \mathrm{L})$, a column flow of 1.1 $\mathrm{mL} / \mathrm{min}$, and an oven program that held at $45^{\circ} \mathrm{C}$ for $84 \mathrm{~s}$ before ramping to $60^{\circ} \mathrm{C}$ at $36^{\circ} \mathrm{C} / \mathrm{min}$ and then holding at $60^{\circ} \mathrm{C}$ for $9 \mathrm{~s}$. In both systems, MS analysis was performed using selected ion monitoring (SIM) for $\mathrm{CH}_{3} \mathrm{Br}(\mathrm{m} / \mathrm{z}=94$ and 96$), \mathrm{CO}_{2}(\mathrm{~m} / \mathrm{z}=44$ and 45), and $\mathrm{CH}_{3} \mathrm{Cl}(\mathrm{m} / \mathrm{z}=50$ and 52). Agilent MassHunter WorkStation Quantitative Analysis 
software was used to quantify the peak area of the major isotopologue of each chemical, while the minor isotopologue was used as a qualifier. For experiments performed in $2 \mathrm{~mL}$ vials, $\mathrm{CH}_{3} \mathrm{X}$ standard curves were generated at each experimental condition by serially diluting $2 \mathrm{mg} / \mathrm{mL}$ liquid $\mathrm{CH}_{3} \mathrm{Br}$ (Restek, 30253) or $\mathrm{CH}_{3} \mathrm{Cl}$ (Restek, 30267) into growth medium. Standards were added to GC vials containing (1 gram) or lacking soil and allowed to equilibrate under experimental conditions for at least 4 hours before measurement.

Soil sampling. Soil was collected from property owned by Nature's Way Resources, a compost facility located in Conroe, TX on February 17, 2020. Soil was sampled from a part of the property not used for compost production, undisturbed since at least 1984 (John Ferguson, pers. comm.). Samples were acquired from the A $(0-10 \mathrm{~cm})$ and B (10$58 \mathrm{~cm}$ ) horizons separately. Each horizon was thoroughly mixed on site, transported to the lab, and immediately stored at $-20^{\circ} \mathrm{C}$ before processing. Samples were oven-dried at $60^{\circ} \mathrm{C}$, passed through a $2 \mathrm{~mm}$ sieve to remove roots and large fragments, and placed in 12-gallon plastic storage bins (Home Depot) prior to storage at room temperature, dry, to minimize organic matter degradation. To sterilize soils, samples were autoclaved for 45 minutes at $120^{\circ} \mathrm{C}$, allowed to rest overnight, and autoclaved again.

Soil characterization. Soil was ground with an agate mortar and pestle prior to chemical analysis. Total $\mathrm{C}, \mathrm{H}$ and $\mathrm{N}$ were measured by catalytic combustion using an elemental analyzer (ECS 4010, Costech) and subsequent chromatographic separation and detection of $\mathrm{CO}_{2}, \mathrm{H}_{2} \mathrm{O}$, and $\mathrm{N}_{2}$. To quantify organic $\mathrm{C}$, inorganic $\mathrm{C}$ was removed using $7 \mathrm{M}$ $\mathrm{HCl}$ acid fumigation in open-top silver capsules ${ }^{60}$. Water extractable halides were measured using an ion chromatograph (Dione ICS-2100, Thermo Scientific). Soil (10 g) 
was suspended in deionized water $(50 \mathrm{~mL})$ and mixed on an orbital shaker (OS-500, VWR) for 2 hours. The suspension was centrifuged, and the supernatant was filtered through a $0.22 \mu \mathrm{m}$ syringe filter. Standard curves for the halides were generated using solutions containing 1,10 , or $100 \mathrm{mg} / \mathrm{L}$ mixtures of $\mathrm{NaCl}, \mathrm{NaBr}$, and $\mathrm{Nal}$. Soil pH was measured using a 1:2 soil/water mixture (w/w) after 30 min equilibrium with atmospheric $\mathrm{CO}_{2}$.

Effect of halides on gas production in soil. MG1655-mht and MG1655 were grown to mid-log phase in M63 medium lacking halides. Cells were resuspended in M63 (100 $\mu \mathrm{L})$ supplemented with a range of $\mathrm{NaBr}$ or $\mathrm{NaCl}(0$ to $100 \mathrm{mM})$ and added to $2 \mathrm{~mL} \mathrm{GC}$ vials containing twice-autoclaved B horizon soil (1 gram) to a water content representing $32 \%$ field capacity; the final cell density was $3 \times 10^{7} \mathrm{CFU} /$ gram soil. For samples hydrated with MIDV1, cultures were grown to mid-log phase in M63 lacking halides and washed thrice in MIDV1 lacking halides. Cells were resuspended in MIDV1 (200 $\mu \mathrm{L})$ supplemented with varying $\mathrm{NaBr}$ or $\mathrm{NaCl}(0$ to $100 \mathrm{mM}$ ) and added to $\mathrm{GC}$ vials containing twice-autoclaved B horizon soil (1 gram) to a water content of $64 \%$ field capacity; the final cell titer was $6 \times 10^{7} \mathrm{CFU} / g r a m$ soil. Samples were sealed and incubated at $22^{\circ} \mathrm{C}$ for 24 hours before headspace gas analysis by GC-MS.

Effect of $\mathbf{N}$ limitation on the gas signal. MG1655-mht were grown to mid-log phase in M63 lacking halides, washed thrice, and resuspended in MIDV1 (20 mM NaBr) containing or lacking nitrogen $(-\mathrm{N})$. Growth medium $(200 \mu \mathrm{L})$ containing $6 \times 10^{7} \mathrm{CFU}$ was added to GC vials containing twice-autoclaved B horizon soil (1 gram) for a water content of $64 \%$ field capacity. For samples containing varying CFU and $\mathrm{NaBr}$, cultures of MG1655-mht were grown to mid-log phase and washed thrice in MIDV1 lacking nitrogen and halides. 
Cells were resuspended in MIDV1 (-N, 0 to $100 \mathrm{mM} \mathrm{NaBr}$ ) and added to twice-autoclaved B horizon soil (1 gram) to a water content representing $64 \%$ field capacity and cell titer of $6 \times 10^{5}, 6 \times 10^{6}$, or $6 \times 10^{7} \mathrm{CFU} /$ gram soil. Samples were sealed and incubated for 24 hours at $22^{\circ} \mathrm{C}$ before headspace gas analysis by GC-MS.

Signal persistence measurements. To assess $\mathrm{CH}_{3} \mathrm{Br}$ stability in liquid cultures, MG1655 carrying a plasmid for constitutive expression of the sfGFP-MHT fusion (pEMF051) were grown to mid-log phase in $\mathrm{M63}$ (100 mM NaBr) containing chloramphenicol (34 $\mu \mathrm{g} / \mathrm{mL})$. Cells were washed thrice, resuspended in M63 (1 mL; -N, $100 \mathrm{mM} \mathrm{NaBr})$ containing chloramphenicol $(34 \mu \mathrm{g} / \mathrm{mL})$, and added to $2 \mathrm{~mL} \mathrm{GC}$ vials at a cell density of $10^{6} \mathrm{CFU} / \mathrm{mL}$. Samples were capped and incubated at $37^{\circ} \mathrm{C}$ while shaking at $250 \mathrm{rpm}$. Each day, matched samples were sacrificed for headspace gas analysis. Immediately after sampling, serial dilutions of each sample were plated on LB-agar medium containing chloramphenicol (34 $\mathrm{gg} / \mathrm{mL}$ ) and incubated overnight at $37^{\circ} \mathrm{C}$ to enable CFU counting. To assess soil effects on $\mathrm{CH}_{3} \mathrm{Br}$ signal, MG1655-mht was grown to mid-log phase in M63 lacking halides, washed thrice, and resuspended in MIDV1 (-N, $20 \mathrm{mM} \mathrm{NaBr})$. Resuspended cells $(200 \mu \mathrm{L})$ were added to twice-autoclaved or unsterilized B horizon soil (1 gram) at a final titer of $6 \times 10^{7} \mathrm{CFU} / \mathrm{gram}$ soil and a water content of $64 \%$ field capacity. Samples were sealed and incubated statically at $22^{\circ} \mathrm{C}$. Each day, matched samples were sacrificed for headspace gas analysis.

Incubation chambers. Fernbach flasks (4420, Pyrex) were fitted with two-holed rubber stoppers (size 13; 14-140Q, Fisher) and sealed around the rim using silicone tape (VP1014, Tommy Tape). A sampling tube assembly was fit into one stopper hole, which consisted of a 2-inch segment of $1 / 4$ " Sulfinert-treated stainless steel tubing (RE22902, 
Restek), a $2 \mu \mathrm{m}$ Siltek-coated frit filter (24171, Restek), a plug valve (SS-4P4T, Swagelok), and a second segment of the same tubing. A second tube assembly lacking the frit filter was fitted into the other hole to enable pressure re-equilibration after sampling. To minimize $\mathrm{CH}_{3} \mathrm{X}$ and microbiological carryover between samples, flasks and stoppers were autoclaved, sampling tubes were soaked in $70 \%$ ethanol, and stoppers were degassed $3 x$ in a vacuum chamber refilled with $\mathrm{N}_{2}$ (Airgas). Samples for TD-GCMS analysis were collected from the chambers using $0.5 \mathrm{~L}$ gas sampling canisters (X20.5L, LabCommerce) that had been evacuated to $<10^{-4}$ mbar using a dry scroll pump (nXDS10i, Edwards). During sampling, canisters were allowed to equilibrate with the chamber headspace for $\sim 15$ seconds. To minimize analyte carryover, canisters were purged with 10 psig He (HE UHP300, Airgas) between experiments.

Thermal desorption. Canisters were connected to an autosampler (CIA Advantage-x, Markes) using transfer lines heated to $120^{\circ} \mathrm{C}$. Samples of varying volume (10 to $400 \mathrm{~mL}$ ) were transferred from the $0.5 \mathrm{~L}$ gas canisters to the TD system at $50 \mathrm{~mL} / \mathrm{min}$ and passed through a water condenser (Kori-xr, Markes) with a cold trap $\left(-30^{\circ} \mathrm{C}\right)$ to remove water. The TD (UNITY-xr, Markes) was equipped with a PAMS focusing trap (U-T20PAM-2S , Markes) that was purged for 1 min with $50 \mathrm{~mL} / \mathrm{min} \mathrm{N}_{2}$ before sample loading at $20^{\circ} \mathrm{C}$. Finally, the trap was desorbed for $1 \mathrm{~min}$ with a split flow of $2 \mathrm{~mL} / \mathrm{min}$ at $280^{\circ} \mathrm{C}$ by ultrapure He carrier gas onto an Agilent 7890B GC fitted with a PoraPLOT Q capillary column (25 $\mathrm{m}, 0.25 \mathrm{~mm}, 8 \mu \mathrm{M}$ film) and connected to an Agilent 5977B MS. With a column flow of $0.9 \mathrm{~mL} / \mathrm{min}$, the $\mathrm{GC}$ oven was heated from $85^{\circ} \mathrm{C}$ to $150^{\circ} \mathrm{C}$ at a rate of $12^{\circ} \mathrm{C} / \mathrm{min}$ and held for $3.5 \mathrm{~min}$. MS settings and data analysis were the same as previously described. Standard curves on the TD-GC-MS were generated by sampling varying volumes (10 to 
$400 \mathrm{~mL}$ ) of a $21 \mathrm{ppb} \mathrm{CH}_{3} \mathrm{Br}, 510 \mathrm{ppb} \mathrm{CH}_{3} \mathrm{Cl}(\mathrm{mol} / \mathrm{mol})$ standard $(10 \%$ analytical uncertainty, balance $\mathrm{N}_{2}$, Airgas). A conversion factor (peak area/volume sampled/ $\mathrm{CH}_{3} \mathrm{X}$ concentration) was calculated from the slope of the standard curve (peak area/volume sampled) and used to calculate $\mathrm{CH}_{3} \mathrm{X}$ concentration in experimental samples using Equation 1:

$$
\mathrm{CH}_{3} X\left(p p b, \frac{\text { mol }}{\text { mol }}\right)=\frac{\left(\frac{\text { measured peak area }}{\text { volume sampled }}\right)}{\text { conversion factor }}
$$

Soil $\mathrm{CH}_{3} \mathrm{X}$ emissions. To assess headspace $\mathrm{CH}_{3} \mathrm{X}$ above soil samples lacking engineered microbes, twice-autoclaved or unsterilized B horizon soil $(1 \mathrm{~kg})$ was added to an incubation chamber and hydrated to $64 \%$ field capacity using MIDV1 medium (-N) with varying $\mathrm{NaBr}$ (0 to $100 \mathrm{mM}$ ). To establish the minimum number of engineered microbes required to yield an indicator gas signal, MG1655-mht cultures were grown to mid-log phase in M63 lacking halides, washed thrice, and resuspended in MIDV1 (-N) containing varying $\mathrm{NaBr}$ (0 to $100 \mathrm{mM}$ ). Unsterilized B horizon soil $(1 \mathrm{~kg}$ ) was then hydrated to $64 \%$ field capacity with this culture $(200 \mathrm{~mL})$ containing the specified cell population in a flask incubation chamber. For both experiments, flasks were sealed and incubated for 48 hours at $22^{\circ} \mathrm{C}$ prior to headspace TD-GC-MS analysis. Ambient samples were taken periodically inside our lab in Houston, TX between June 2021 and December 2021.

IPTG sensing in soil. To see if soil affects IPTG bioavailability, MIDV1 (100 $\mu$ L; -N, 20 $\mathrm{mM} \mathrm{NaBr}$ ) with varying concentrations of IPTG (0 to $1 \mathrm{mM})$ was added to empty $\mathrm{GC}$ vials and vials containing unsterilized B horizon soil (1 gram). Cultures of MG1655 transformed with pLC7 were grown to mid-log phase in M63 lacking halides and containing 
chloramphenicol $(34 \mu \mathrm{g} / \mathrm{mL})$. Cultures were washed thrice, resuspended in MIDV1 (-N; $20 \mathrm{mM} \mathrm{NaBr})$ containing chloramphenicol $(34 \mu \mathrm{g} / \mathrm{mL})$, and added $(100 \mu \mathrm{L})$ to the vials containing varying IPTG concentrations at a final cell population of $6 \times 10^{7}$ CFU. Soil samples had a total water content of $64 \%$ field capacity. Samples were incubated at $22^{\circ} \mathrm{C}$ for 24 hours before headspace gas analysis. To benchmark indicator gas signals from the IPTG sensing strain against signals MG1655- $m h t$, unsterilized B horizon soil (1 gram) was hydrated with MIDV1 (100 $\mu \mathrm{L} ;-\mathrm{N}, 100 \mathrm{mM} \mathrm{NaBr})$ with or without IPTG (0 or $1 \mathrm{mM})$ in GC vials. Cultures of MG1655-mht and MG1655-IPTG were grown to mid-log phase in M63 lacking halides, with chloramphenicol $(34 \mu \mathrm{g} / \mathrm{mL})$ for the IPTG sensor only. Cells were washed thrice in MIDV1 (-N; $100 \mathrm{mM} \mathrm{NaBr}$ ) without antibiotics, resuspended in the same medium, and added $(100 \mu \mathrm{L})$ to the soil at a final cell density of $6 \times 10^{7} \mathrm{CFU} / \mathrm{gram}$; the total water content was $64 \%$ field capacity. Headspace gas was analyzed following a 24-hour incubation at $22^{\circ} \mathrm{C}$. To investigate whether MG1655-IPTG presented a significant signal over background when added at a titer of $10^{3} \mathrm{CFU} / g$ ram soil, unsterilized $\mathrm{B}$ horizon soil $(1 \mathrm{~kg})$ was hydrated with MIDV1 $(100 \mathrm{~mL} ;-\mathrm{N}, 100 \mathrm{mM} \mathrm{NaBr})$ with or without IPTG (0 or $1 \mathrm{mM}$ ). Mid-log phase cultures of MG1655-IPTG in M63 lacking halides and containing chloramphenicol $(34 \mu \mathrm{g} / \mathrm{mL})$ were washed thrice and resuspended in MIDV1 (-N, $100 \mathrm{mM}$ $\mathrm{NaBr})$. Cultures $(100 \mathrm{~mL})$ were added to the pre-hydrated soils at a final density of $10^{3}$ CFU/gram soil and final water content of $64 \%$ field capacity. Sealed flasks were incubated at $22^{\circ} \mathrm{C}$ for 48 hours before gas analysis. 


\section{SUPPORTING INFORMATION}

Supplementary Tables: (S1) Soil particle size distributions, (S2) soil mineralogy, and (S3) plasmids used in this study.

Supplementary Figures: (S1) Soil XRD spectra, (S2) soil water retention curves, (S3) cell and halide titrations, (S4) E. coli survival in liquid medium, (S5) $\mathrm{CH}_{3} \mathrm{Br}$ standard persistence, (S6) E. coli survival in soil, (S7) TD-GC-MS methodology, and (S8) standard curves and ambient $\mathrm{CH}_{3} \mathrm{X}$.

Supplementary Methods: (i) Materials and strains, (ii) soil particle size distribution, (iii) soil mineralogy, (iv) soil water retention curves, (v) indicator gas stability and cell viability, (vi) cell viability in untreated soil, and (vii) comparing GC-MS and TD-GC-MS measurements. 


\section{ACKNOWLEDGEMENTS}

We are grateful for financial support from the Defense Advanced Research Projects Agency HR0011-19-2-0019 (to C.A.M. and J.J.S.) and Gordon and Betty Moore Foundation (to C.A.M. and J.J.S.). Additionally, this research was supported by the US Department of Energy, Office of Science, through the Genomic Science Program, Office of Biological and Environmental Research, under FWP 78814 at PNNL. PNNL is a multiprogram national laboratory operated by Battelle for the DOE under Contract DE-AC0576RLO 1830. We would like to thank Imna Melendez, Jennifer Vu, Cassia Lewandowski, and Angela Sanchez for their technical support. 


\section{REFERENCES}

(1) Kuzyakov, Y.; Blagodatskaya, E. Microbial Hotspots and Hot Moments in Soil: Concept \& Review. Soil Biol. Biochem. 2015, 83, 184-199. DOI: 10.1016/j.soilbio.2015.01.025.

(2) Jansson, J. K.; Hofmockel, K. S. The Soil Microbiome-from Metagenomics to Metaphenomics. Curr. Opin. Microbiol. 2018, 43, 162-168. DOI: 10.1016/j.mib.2018.01.013.

(3) Trivedi, P.; Leach, J. E.; Tringe, S. G.; Sa, T.; Singh, B. K. Plant-Microbiome Interactions: From Community Assembly to Plant Health. Nat. Rev. Microbiol. 2020, 18 (11), 607-621. DOI: 10.1038/s41579-020-0412-1.

(4) Del Valle, I.; Fulk, E. M.; Kalvapalle, P.; Silberg, J. J.; Masiello, C. A.; Stadler, L. B. Translating New Synthetic Biology Advances for Biosensing Into the Earth and Environmental Sciences. Front. Microbiol. 2021, 11. DOI: 10.3389/fmicb.2020.618373.

(5) King, J. M. H.; DiGrazia, P. M.; Applegate, B.; Burlage, R.; Sanseverino, J.; Dunbar, P.; Larimer, F.; Sayler, G. S. Rapid, Sensitive Bioluminescent Reporter Technology for Naphthalene Exposure and Biodegradation. Science 1990, 249 (4970), 778-781. DOI: 10.1126/science.249.4970.778.

(6) DeAngelis, K. M.; Ji, P.; Firestone, M. K.; Lindow, S. E. Two Novel Bacterial Biosensors for Detection of Nitrate Availability in the Rhizosphere. Appl. Environ. Microbiol. 2005, 71 (12), 8537-8547. DOI: 10.1128/AEM.71.12.8537-8547.2005.

(7) DeAngelis, K. M.; Firestone, M. K.; Lindow, S. E. Sensitive Whole-Cell Biosensor Suitable for Detecting a Variety of N-Acyl Homoserine Lactones in Intact Rhizosphere Microbial Communities. Appl. Environ. Microbiol. 2007, 73 (11), 3724-3727. DOI: 10.1128/AEM.02187-06.

(8) Cheng, H.-Y.; Masiello, C. A.; Bennett, G. N.; Silberg, J. J. Volatile Gas Production by Methyl Halide Transferase: An In Situ Reporter Of Microbial Gene Expression In Soil. Environ. Sci. Technol. 2016, 50 (16), 8750-8759. DOI: 10.1021/acs.est.6b01415.

(9) Zhu, H.; Gonzalez, R.; Bobik, T. A. Coproduction of Acetaldehyde and Hydrogen during Glucose Fermentation by Escherichia Coli. Appl. Environ. Microbiol. 2011, 77 (18), $6441-$ 6450. DOI: 10.1128/AEM.05358-11.

(10) Bongers, R. S.; Hoefnagel, M. H. N.; Kleerebezem, M. High-Level Acetaldehyde Production in Lactococcus Lactis by Metabolic Engineering. Appl. Environ. Microbiol. 2005, 71 (2), 1109-1113. DOI: 10.1128/AEM.71.2.1109-1113.2005.

(11) Bang, S.-W.; Clark, D. S.; Keasling, J. D. Engineering Hydrogen Sulfide Production and Cadmium Removal by Expression of the Thiosulfate Reductase Gene (PhsABC) from 
Salmonella Enterica Serovar Typhimurium in Escherichia Coli. Appl. Environ. Microbiol. 2000, 66 (9), 3939-3944. DOI: 10.1128/AEM.66.9.3939-3944.2000.

Cheng, H.-Y.; Masiello, C. A.; Del Valle, I.; Gao, X.; Bennett, G. N.; Silberg, J. J. Ratiometric Gas Reporting: A Nondisruptive Approach To Monitor Gene Expression in Soils. ACS Synth. Biol. 2018, 7 (3), 903-911. DOI: 10.1021/acssynbio.7b00405.

(13) Chien, T.; Jones, D. R.; Danino, T. Engineered Bacterial Production of Volatile Methyl Salicylate. ACS Synth. Biol. 2021, 10 (1), 204-208. DOI: 10.1021/acssynbio.0c00497.

(14) Wuosmaa, A. M.; Hager, L. P. Methyl Chloride Transferase: A Carbocation Route for Biosynthesis of Halometabolites. Science 1990, 249 (4965), 160-162. DOI: 10.1126/science.2371563.

(15) Del Valle, I.; Webster, T. M.; Cheng, H.-Y.; Thies, J. E.; Kessler, A.; Miller, M. K.; Ball, Z. T.; MacKenzie, K. R.; Masiello, C. A.; Silberg, J. J.; Lehmann, J. Soil Organic Matter Attenuates the Efficacy of Flavonoid-Based Plant-Microbe Communication. Sci. Adv. 2020, 6 (5), eaax8254. DOI: 10.1126/sciadv.aax8254.

(16) Del Valle, I.; Gao, X.; Ghezzehei, T.; Silberg, J. J.; Masiello, C. A. Artificial Soils Reveal Individual Factor Controls on Microbial Processes. bioRxiv. DOI: 10.1101/2022.02.01.478713.

(17) Redeker, K. R.; Cicerone, R. J. Environmental Controls over Methyl Halide Emissions from Rice Paddies. Global Biogeochem. Cycles 2004, 18 (1), GB1027. DOI: 10.1029/2003GB002092.

(18) Tkacz, A.; Hortala, M.; Poole, P. S. Absolute Quantitation of Microbiota Abundance in Environmental Samples. Microbiome 2018, 6 (1), 110. DOI: 10.1186/s40168-018-0491-7.

(19) Zhang, Z.; Qu, Y.; Li, S.; Feng, K.; Wang, S.; Cai, W.; Liang, Y.; Li, H.; Xu, M.; Yin, H.; Deng, Y. Soil Bacterial Quantification Approaches Coupling with Relative Abundances Reflecting the Changes of Taxa. Sci. Rep. 2017, 7 (1), 4837. DOI: 10.1038/s41598-01705260-w.

(20) Yang, L.; Lou, J.; Wang, H.; Wu, L.; Xu, J. Use of an Improved High-Throughput Absolute Abundance Quantification Method to Characterize Soil Bacterial Community and Dynamics. Sci. Total Environ. 2018, 633, 360-371. DOI: 10.1016/j.scitotenv.2018.03.201.

(21) Watt, M.; Hugenholtz, P.; White, R.; Vinall, K. Numbers and Locations of Native Bacteria on Field-Grown Wheat Roots Quantified by Fluorescence in Situ Hybridization (FISH). Environ. Microbiol. 2006, 8 (5), 871-884. DOI: 10.1111/j.1462-2920.2005.00973.x. 
(22) DeAngelis, K. M.; Lindow, S. E.; Firestone, M. K. Bacterial Quorum Sensing and Nitrogen Cycling in Rhizosphere Soil. FEMS Microbiol. Ecol. 2008, 66 (2), 197-207. DOI: 10.1111/j.1574-6941.2008.00550.x.

(23) Dundore-Arias, J. P.; Castle, S. C.; Felice, L.; Dill-Macky, R.; Kinkel, L. L. Carbon Amendments Influence Composition and Functional Capacities of Indigenous Soil Microbiomes. Front. Mol. Biosci. 2020, 6. DOI: 10.3389/fmolb.2019.00151.

(24) Wheatley, R. E.; Ritz, K.; Crabb, D.; Caul, S. Temporal Variations in Potential Nitrification Dynamics in Soil Related to Differences in Rates and Types of Carbon and Nitrogen Inputs. Soil Biol. Biochem. 2001, 33 (15), 2135-2144. DOI: 10.1016/S0038-0717(01)00148-1.

(25) Wang, C.; Liu, D.; Bai, E. Decreasing Soil Microbial Diversity Is Associated with Decreasing Microbial Biomass under Nitrogen Addition. Soil Biol. Biochem. 2018, 120, 126-133. DOI: 10.1016/j.soilbio.2018.02.003.

(26) WMO (World Meteorological Organization), Scientific Assessment of Ozone Depletion: 2018, Global Ozone Research and Monitoring Project-Report No. 58, 588 pp., Geneva, Switzerland, 2018. https://www.esrl.noaa.gov/csd/assessments/ozone/2018 (accessed 2021-05-24).

(27) Redeker, K. R.; Cai, L. L.; Dumbrell, A. J.; Bardill, A.; Chong, J. P. J.; Helgason, T. Chapter Four - Noninvasive Analysis of the Soil Microbiome: Biomonitoring Strategies Using the Volatilome, Community Analysis, and Environmental Data. In Advances in Ecological Research (Bohan, D. A., Dumbrell, A. J., Woodward, G., Jackson, M., Eds.); Next Generation Biomonitoring: Part 2; Academic Press, 2018; Vol. 59, pp 93-132. DOI: 10.1016/bs.aecr.2018.07.001.

(28) Rhew, R. C.; Teh, Y. A.; Abel, T. Methyl Halide and Methane Fluxes in the Northern Alaskan Coastal Tundra. J. Geophys. Res.: Biogeosci. 2007, 112 (G2), G02009. DOI: 10.1029/2006JG000314.

(29) Redeker, K. R.; Kalin, R. M. Methyl Chloride Isotopic Signatures from Irish Forest Soils and a Comparison between Abiotic and Biogenic Methyl Halide Soil Fluxes. Glob. Change Biol. 2012, 18 (4), 1453-1467. DOI: 10.1111/j.1365-2486.2011.02600.x.

(30) Ni, X.; Hager, L. P. Expression of Batis Maritima Methyl Chloride Transferase in Escherichia Coli. Proc. Natl. Acad. Sci. U.S.A. 1999, 96 (7), 3611-3615. DOI: 10.1073/pnas.96.7.3611.

(31) Brennan, F. P.; Grant, J.; Botting, C. H.; O’Flaherty, V.; Richards, K. G.; Abram, F. Insights into the Low-Temperature Adaptation and Nutritional Flexibility of a Soil-Persistent Escherichia Coli. FEMS Microbiol. Ecol. 2013, 84 (1), 75-85. DOI: 10.1111/15746941.12038. 
(32) Horst, A.; Bonifacie, M.; Bardoux, G.; Richnow, H. H. Isotopic Characterization (2H, 13C, $37 \mathrm{Cl}, 81 \mathrm{Br}$ ) of Abiotic Degradation of Methyl Bromide and Methyl Chloride in Water and Implications for Future Studies. Environ. Sci. Technol. 2019, 53 (15), 8813-8822. DOI: 10.1021/acs.est.9b02165.

(33) Jeffers, P. M.; Wolfe, N. L. On the Degradation of Methyl Bromide in Sea Water. Geophys. Res. Lett. 1996, 23 (14), 1773-1776. DOI: 10.1029/96GL01670.

(34) King, D. B.; Saltzman, E. S. Removal of Methyl Bromide in Coastal Seawater: Chemical and Biological Rates. J. Geophys. Res.: Oceans 1997, 102 (C8), 18715-18721. DOI: 10.1029/97JC01214.

(35) Chaignaud, P.; Morawe, M.; Besaury, L.; Kröber, E.; Vuilleumier, S.; Bringel, F.; Kolb, S. Methanol Consumption Drives the Bacterial Chloromethane Sink in a Forest Soil. ISME J. 2018, 12 (11), 2681-2693. DOI: 10.1038/s41396-018-0228-4.

(36) Hines, M. E.; Crill, P. M.; Varner, R. K.; Talbot, R. W.; Shorter, J. H.; Kolb, C. E.; Harriss, R. C. Rapid Consumption of Low Concentrations of Methyl Bromide by Soil Bacteria. Appl. Environ. Microbiol.1998. https://doi.org/10.1128/AEM.64.5.1864-1870.1998.

(37) McDonald, I. R.; Warner, K. L.; McAnulla, C.; Woodall, C. A.; Oremland, R. S.; Murrell, J. C. A Review of Bacterial Methyl Halide Degradation: Biochemistry, Genetics and Molecular Ecology. Environ. Microbiol. 2002, 4 (4), 193-203. DOI: 10.1046/j.14622920.2002.00290.x.

(38) Rhew, R. C.; Aydin, M.; Saltzman, E. S. Measuring Terrestrial Fluxes of Methyl Chloride and Methyl Bromide Using a Stable Isotope Tracer Technique. Geophys. Res. Lett. 2003, 30 (21). DOI: 10.1029/2003GL018160.

(39) Zhang, W.; Jiao, Y.; Zhu, R.; Rhew, R. C. Methyl Chloride and Methyl Bromide Production and Consumption in Coastal Antarctic Tundra Soils Subject to Sea Animal Activities. Environ. Sci. Technol. 2020, 54 (20), 13354-13363. DOI: 10.1021/acs.est.0c04257.

(40) Jiao, Y.; Ruecker, A.; Deventer, M. J.; Chow, A. T.; Rhew, R. C. Halocarbon Emissions from a Degraded Forested Wetland in Coastal South Carolina Impacted by Sea Level Rise. ACS Earth Space Chem. 2018, 2 (10), 955-967. DOI: 10.1021/acsearthspacechem.8b00044.

(41) Lutz, R.; Bujard, H. Independent and Tight Regulation of Transcriptional Units in Escherichia Coli via the LacR/O, the TetR/O and AraC/I1-I2 Regulatory Elements. Nucleic Acids Res. 1997, 25 (6), 1203-1210. DOI: 10.1093/nar/25.6.1203. 
(42) Watling, R.; Harper, D. B. Chloromethane Production by Wood-Rotting Fungi and an Estimate of the Global Flux to the Atmosphere. Mycol. Res. 1998, 102 (7), 769-787. DOI: 10.1017/S0953756298006157.

(43) Redeker, K. R.; Treseder, K. K.; Allen, M. F. Ectomycorrhizal Fungi: A New Source of Atmospheric Methyl Halides? Glob. Change Biol. 2004, 10 (6), 1009-1016. DOI: 10.1111/j.1529-8817.2003.00782.x.

(44) Groszko, W.; Moore, R. M. Ocean-Atmosphere Exchange of Methyl Bromide: NW Atlantic and Pacific Ocean Studies. J. Geophys. Res.: Atmos. 1998, 103 (D13), 16737-16741. https://doi.org/10.1029/98JD00111.

(45) Moore, R. M.; Groszko, W.; Niven, S. J. Ocean-Atmosphere Exchange of Methyl Chloride: Results from NW Atlantic and Pacific Ocean Studies. J. Geophys. Res.: Oceans 1996, 101 (C12), 28529-28538. https://doi.org/10.1029/96JC02915.

(46) Huang, W. L.; Bu, X.; Nguyen, L.; Gammon, R. H.; Bullister, J. L. Production and Consumption of Methyl Halides in a Freshwater Lake. Limnol. Oceanogr. 2000, 45 (7), 1537-1545. DOI: 10.4319/lo.2000.45.7.1537.

(47) Ruecker, A.; Weigold, P.; Behrens, S.; Jochmann, M.; Laaks, J.; Kappler, A. Predominance of Biotic over Abiotic Formation of Halogenated Hydrocarbons in Hypersaline Sediments in Western Australia. Environ. Sci. Technol. 2014, 48 (16), 9170-9178. DOI: 10.1021/es501810g.

(48) Teh, Y. A.; Rhew, R. C.; Atwood, A.; Abel, T. Water, Temperature, and Vegetation Regulation of Methyl Chloride and Methyl Bromide Fluxes from a Shortgrass Steppe Ecosystem. Glob. Change Biol. 2008, 14 (1), 77-91. DOI: 10.1111/j.13652486.2007.01480.x.

(49) Manley, S. L.; Wang, N.-Y.; Walser, M. L.; Cicerone, R. J. Coastal Salt Marshes as Global Methyl Halide Sources from Determinations of Intrinsic Production by Marsh Plants. Glob. Biogeochem. Cycles 2006, 20 (3). DOI: 10.1029/2005GB002578.

(50) Keppler, F.; Eiden, R.; Niedan, V.; Pracht, J.; Schöler, H. F. Halocarbons Produced by Natural Oxidation Processes during Degradation of Organic Matter. Nature 2000, 403 (6767), 298-301. DOI: 10.1038/35002055.

(51) Yu, J.; Li, Y.; Han, G.; Zhou, D.; Fu, Y.; Guan, B.; Wang, G.; Ning, K.; Wu, H.; Wang, J. The Spatial Distribution Characteristics of Soil Salinity in Coastal Zone of the Yellow River Delta. Environ. Earth Sci. 2014, 72 (2), 589-599. DOI: 10.1007/s12665-013-2980-0. 
(52) Moyano, F. E.; Manzoni, S.; Chenu, C. Responses of Soil Heterotrophic Respiration to Moisture Availability: An Exploration of Processes and Models. Soil Biol. Biochem. 2013, 59, 72-85. DOI: 10.1016/j.soilbio.2013.01.002.

(53) Khan, M. a. H.; Whelan, M. E.; Rhew, R. C. Effects of Temperature and Soil Moisture on Methyl Halide and Chloroform Fluxes from Drained Peatland Pasture Soils. J. Environ. Monit. 2012, 14 (1), 241-249. DOI: 10.1039/C1EM10639B.

(54) Teh, Y. A.; Mazéas, O.; Atwood, A. R.; Abel, T.; Rhew, R. C. Hydrologic Regulation of Gross Methyl Chloride and Methyl Bromide Uptake from Alaskan Arctic Tundra. Global Change Biology 2009, 15 (2), 330-345. DOI: 10.1111/j.1365-2486.2008.01749.x.

(55) Luo, H.; Hansen, A. S. L.; Yang, L.; Schneider, K.; Kristensen, M.; Christensen, U.; Christensen, H. B.; Du, B.; Özdemir, E.; Feist, A. M.; Keasling, J. D.; Jensen, M. K.; Herrgård, M. J.; Palsson, B. O. Coupling S-Adenosylmethionine-Dependent Methylation to Growth: Design and Uses. PLoS Biol. 2019, 17 (3), e2007050. DOI: 10.1371/journal.pbio.2007050.

(56) Atkinson, J. T.; Jones, A. M.; Zhou, Q.; Silberg, J. J. Circular Permutation Profiling by Deep Sequencing Libraries Created Using Transposon Mutagenesis. Nucleic Acids Res.2018, 46 (13), e76. DOI: 10.1093/nar/gky255.

(57) Mutalik, V. K.; Guimaraes, J. C.; Cambray, G.; Lam, C.; Christoffersen, M. J.; Mai, Q.-A.; Tran, A. B.; Paull, M.; Keasling, J. D.; Arkin, A. P.; Endy, D. Precise and Reliable Gene Expression via Standard Transcription and Translation Initiation Elements. Nat. Methods 2013, 10 (4), 354-360. DOI: 10.1038/nmeth.2404.

(58) Pédelacq, J.-D.; Cabantous, S.; Tran, T.; Terwilliger, T. C.; Waldo, G. S. Engineering and Characterization of a Superfolder Green Fluorescent Protein. Nat. Biotechnol. 2006, 24 (1), 79-88. DOI: 10.1038/nbt1172.

(59) Engler, C.; Kandzia, R.; Marillonnet, S. A One Pot, One Step, Precision Cloning Method with High Throughput Capability. PLoS ONE 2008, 3 (11), e3647. DOI: 10.1371/journal.pone.0003647.

(60) Harris, D.; Horwáth, W. R.; van Kessel, C. Acid Fumigation of Soils to Remove Carbonates Prior to Total Organic Carbon or CARBON-13 Isotopic Analysis. Soil Sci. Soc. Am. J. 2001, 65 (6), 1853-1856. DOI: 10.2136/sssaj2001.1853. 
a

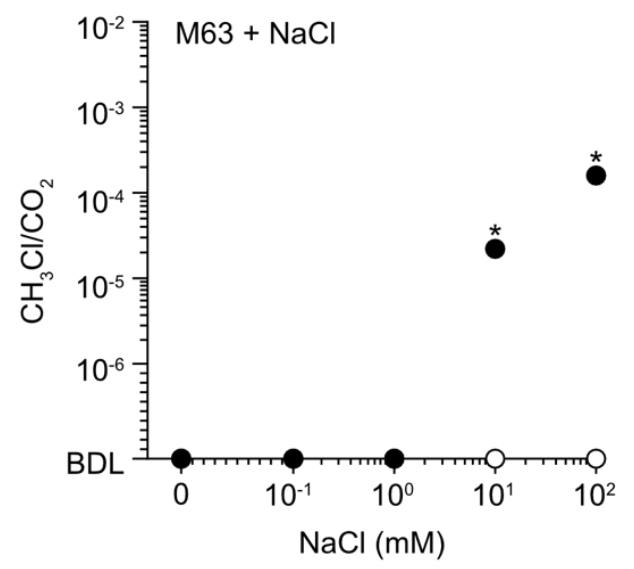

C

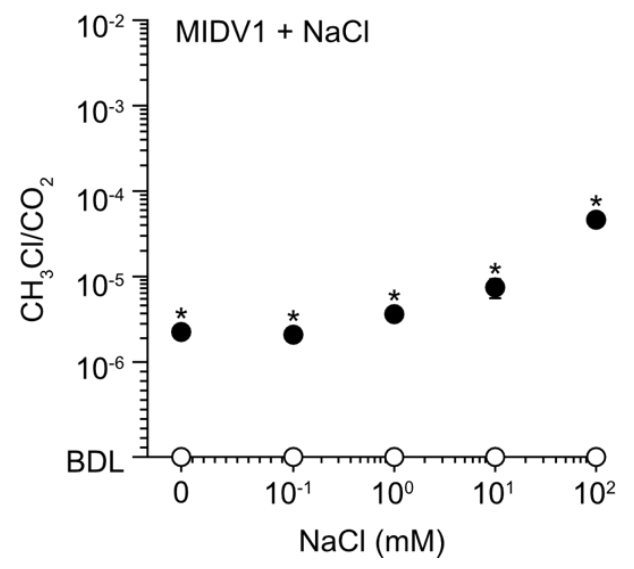

b

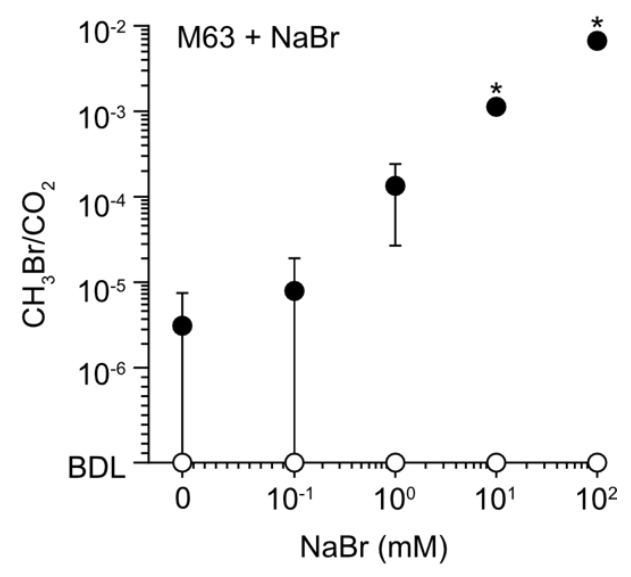

d

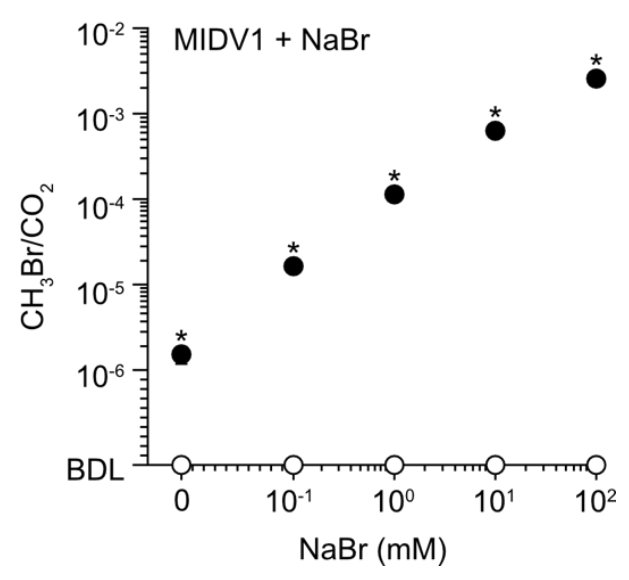

Figure 1. Effect of halide augmentation on the indicator gas signal in soil. (a) $\mathrm{CH}_{3} \mathrm{Cl}$ and (b) $\mathrm{CH}_{3} \mathrm{Br}$ signals in the headspace of autoclaved $\mathrm{B}$ horizon soil (1 gram) hydrated to $32 \%$ field capacity with M63 containing $10^{7} \mathrm{CFU} / \mathrm{gram}$ soil of MG1655-mht (•) or wildtype MG1655 (०) and varying concentrations of halides. The $\mathrm{CH}_{3} \mathrm{X}$ signal was measured after a 24 -hour incubation at $22^{\circ} \mathrm{C}$ and normalized to $\mathrm{CO}_{2}$ to account for cellular respiration. Only samples supplemented with $\geq 10 \mathrm{mM}$ halide presented a $\mathrm{CH}_{3} \mathrm{X}$ signal significantly above background ( $\left.{ }^{*}, \mathrm{p}<0.01\right)$. (c) $\mathrm{CH}_{3} \mathrm{Cl}$ and (d) $\mathrm{CH}_{3} \mathrm{Br}$ signal from autoclaved $\mathrm{B}$ horizon soil (1 gram) hydrated to $64 \%$ field capacity with MIDV1 containing $10^{7} \mathrm{CFU} /$ gram soil of MG1655-mht (•) or wildtype MG1655 (०) and varying concentrations of halide ( 0 to $100 \mathrm{mM}$ ). The $\mathrm{CH}_{3} \mathrm{X}$ signal was significantly above background at all halide concentrations $\left({ }^{*}, p<0.01\right)$. Data represent the average of three biological replicates, while error bars represent \pm 1 standard deviation. $p$-values were calculated using a two-sided, independent $t$ test. BDL, below detection limit. 

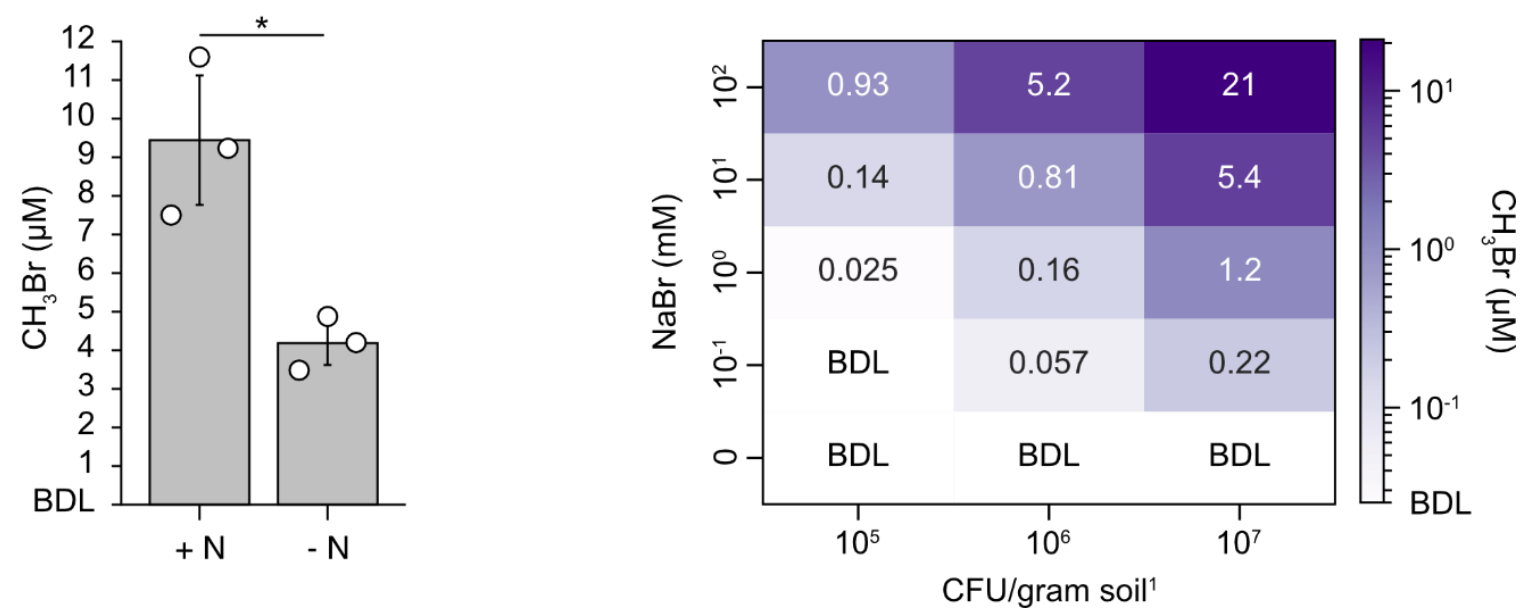

Figure 2. Nitrogen limitation decreases the gas reporter signal in soil. (a) $\mathrm{CH}_{3} \mathrm{Br}$ signal presented by MG1655-mht (10 CFU/gram soil) in soil containing (+N) or lacking ($\mathrm{N})$ nitrogen. Autoclaved B horizon soil (1 gram) hydrated to $64 \%$ field capacity with MIDV1 (20 mM NaBr) was incubated at $22^{\circ} \mathrm{C}$ for 24 hours before headspace gas analysis. Indicator gas signals from samples lacking nitrogen were significantly decreased from samples containing nitrogen $(\mathrm{p}=0.01)$. (b) $\mathrm{CH}_{3} \mathrm{Br}$ signal presented by varying titers of MG1655- $m$ ht in autoclaved B horizon soil (1 gram) hydrated to the same field capacity with MIDV1 (-N) containing varying amounts of $\mathrm{NaBr}$. Samples were incubated at $22^{\circ} \mathrm{C}$ for 24 hours prior to gas analysis. Values shown represent the average of three biological replicates, with the individual data points are shown as open circles. p-values were calculated using a two-sided, independent $t$ test. Error bars represent \pm 1 standard deviation. BDL, below detection limit. 
a

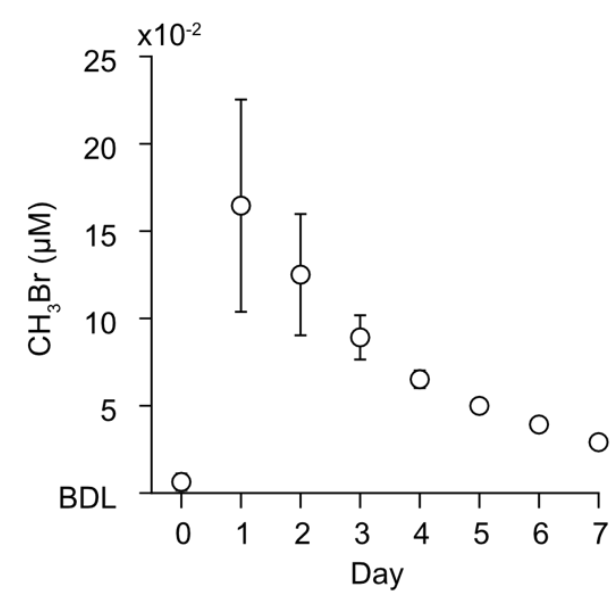

C

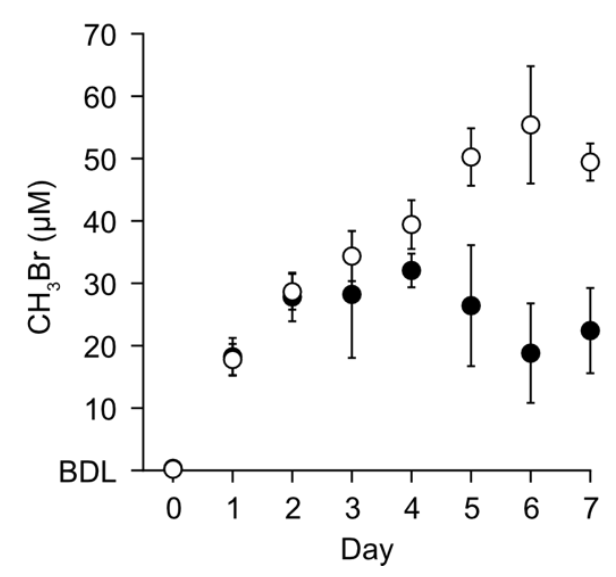

b

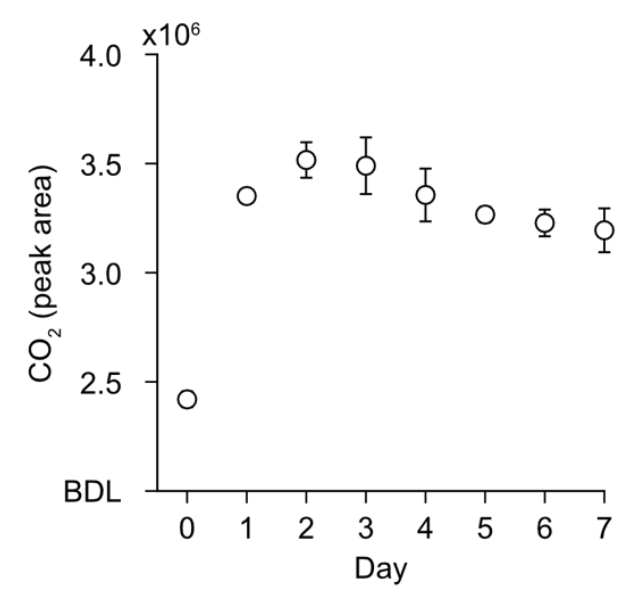

d

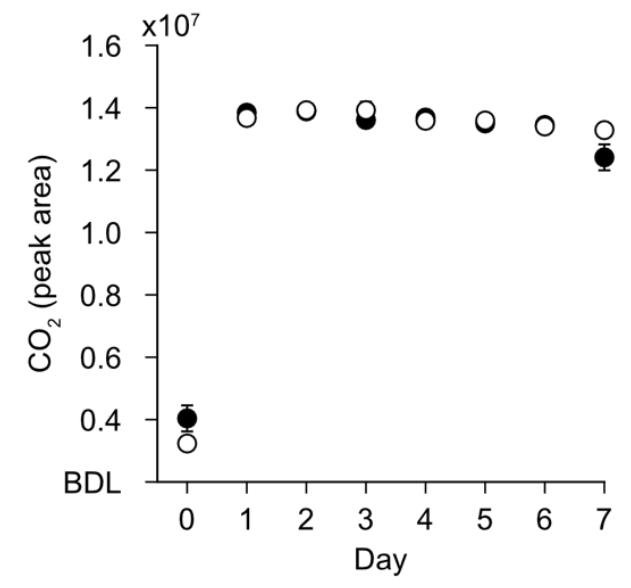

Figure 3. Indicator gas signal persistence. (a) $\mathrm{CH}_{3} \mathrm{Br}$ and (b) $\mathrm{CO}_{2}$ accumulation in liquid samples containing MG1655- $\mathrm{mht}\left(10^{6} \mathrm{CFU} / \mathrm{mL}\right)$ in $\mathrm{M} 63(1 \mathrm{~mL} ;-\mathrm{N}, 100 \mathrm{mM} \mathrm{NaBr}$ ). Identical samples were incubated in sealed GC-MS vials at $37^{\circ} \mathrm{C}$ while shaking at 250 rpm, and matched samples were sacrificed for gas analysis every 24 hours. (c) $\mathrm{CH}_{3} \mathrm{Br}$ and (d) $\mathrm{CO}_{2}$ generated by MG1655- $\mathrm{mht}\left(10^{7} \mathrm{CFU} / \mathrm{gram}\right.$ soil) added to either unsterilized $(\bullet)$ or autoclaved (०) B horizon soil (1 gram) hydrated to $64 \%$ field capacity with MIDV1 $(-\mathrm{N} ; 20 \mathrm{mM} \mathrm{NaBr})$. Samples were incubated without shaking at $22^{\circ} \mathrm{C}$ in sealed vials. Data represent the average of three biological replicates. Error bars represent \pm 1 standard deviation. BDL, below detection limit. 
a

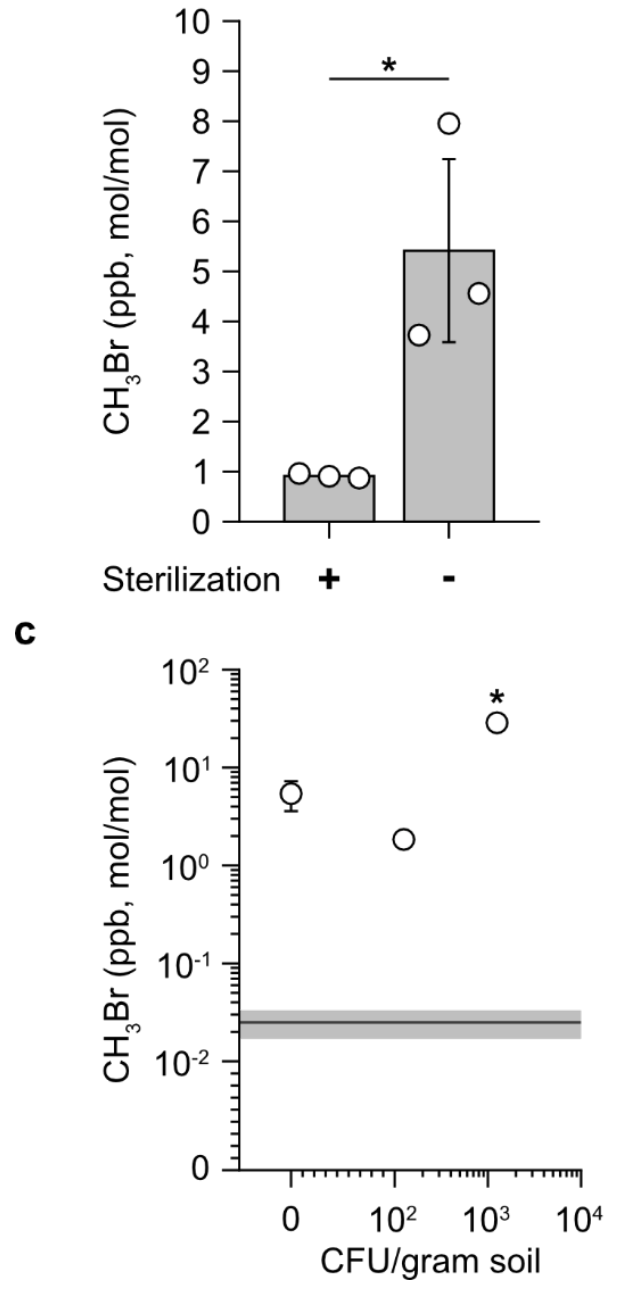

b

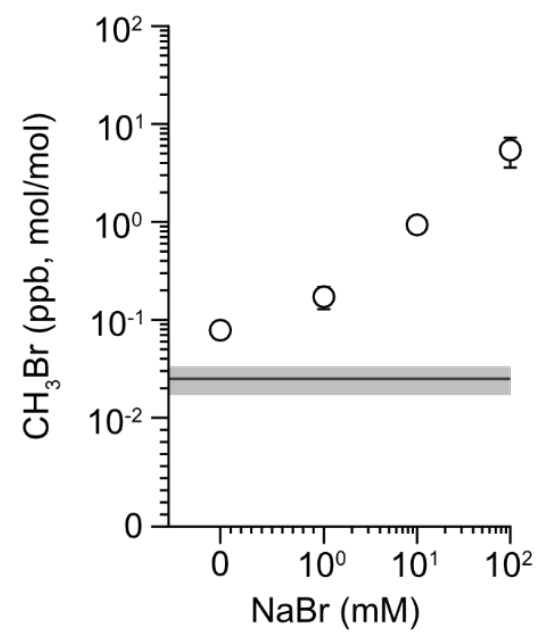

d

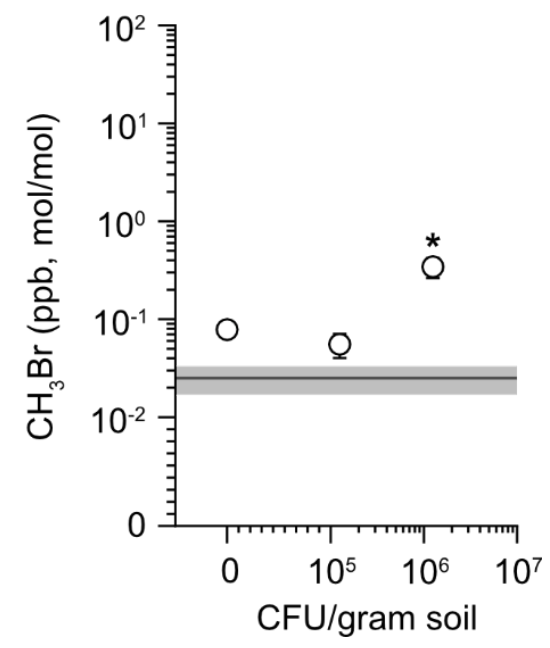

Figure 4. Effect of gas concentration on signal detection. (a) $\mathrm{CH}_{3} \mathrm{Br}$ from an autoclaved (+) and unsterilized (-) B horizon soil $(1 \mathrm{~kg})$ that had been hydrated to $64 \%$ field capacity with MIDV1 (-N; $100 \mathrm{mM} \mathrm{NaBr})$ and incubated for 48 hours at $22^{\circ} \mathrm{C}$. Unsterilized soil presents a significantly higher signal $\left({ }^{*}, p=0.025\right)$ than autoclaved soil. (b) Effect of $\mathrm{NaBr}$ augmentation on $\mathrm{CH}_{3} \mathrm{Br}$ produced by unsterilized $\mathrm{B}$ horizon soil that was similarly hydrated. All samples presented significantly higher $\mathrm{CH}_{3} \mathrm{Br}(\mathrm{p}<0.01)$ than ambient, which is shown as a line. (c) Effect of MG1655-mht titer on the gas signal from unsterilized $B$ horizon soil hydrated with MIDV1 $(-\mathrm{N}, 100 \mathrm{mM} \mathrm{NaBr})$ to the same water content. A MG1655-mht titer of $10^{3} \mathrm{CFU} / \mathrm{gram}$ soil was required to present a signal significantly above the no-cell background $\left({ }^{*}, p=0.001\right)$. (d) Effect of MG1655- $m h t$ titer on the headspace gas signal from unsterilized $B$ horizon soil hydrated to the same water content with MIDV1 (-N) lacking supplemental halides. A higher cell titer $\left(10^{6} \mathrm{CFU} / \mathrm{gram}\right.$ soil) was required for a significant signal above the no-cell control $\left({ }^{*}, p=0.01\right)$. Data represent the average of three biological replicates, while error bars represent \pm 1 standard deviation. Average ambient concentration (dark gray line) is plotted \pm 1 standard deviation (light gray bar). $p$-values were calculated using a two-sided, independent $t$ test. 
a

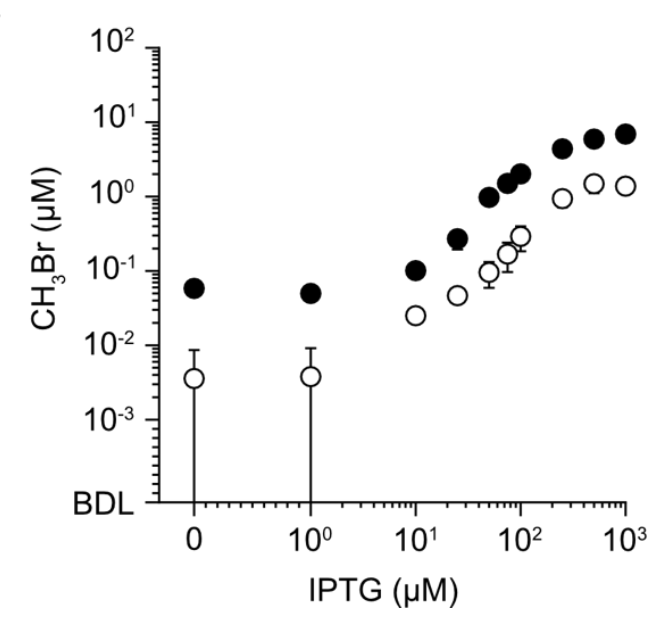

b

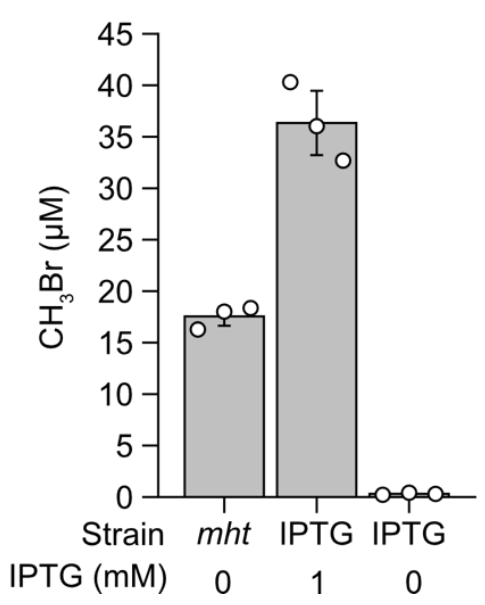

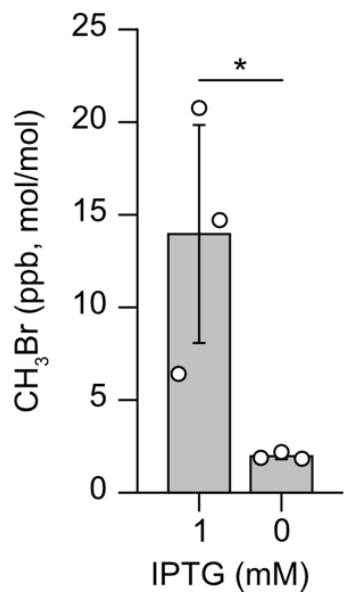

Figure 5. Chemical sensing in soil. (a) Effect of IPTG on $\mathrm{CH}_{3} \mathrm{Br}$ produced by MG1655IPTG. MIDV1 (-N; $20 \mathrm{mM} \mathrm{NaBr})$ with chloramphenicol $(34 \mu \mathrm{g} / \mathrm{mL})$ and varying IPTG was added to $2 \mathrm{~mL} \mathrm{GC-MS}$ vials containing $(\bullet)$ or lacking $(\circ)$ unsterilized B horizon soil $(1$ gram). Cells $\left(10^{8} \mathrm{CFU}\right)$ in the same medium were added to each vial, yielding soil samples hydrated to $64 \%$ field capacity. Headspace gas was measured after 24 hours incubation at $22^{\circ} \mathrm{C}$. (b) Indicator gas signals from MG1655-mht ( $\left.m h t\right)$ and MG1655-IPTG (IPTG) at a titer of $6 \times 10^{7} \mathrm{CFU}$ in unsterilized $\mathrm{B}$ horizon soil (1 gram) hydrated to the same water content with MIDV1 (-N; $100 \mathrm{mM} \mathrm{NaBr}$ ) containing or lacking IPTG. Headspace gas was measured following 24 hours of incubation at $22^{\circ} \mathrm{C}$ (c) TD enables detection of IPTG in an unsterilized B horizon soil $(1 \mathrm{~kg}$ ) hydrated to 64\% field capacity with MIDV1 (-N; 100 $\mathrm{mM} \mathrm{NaBr}$ ) and containing $10^{3} \mathrm{CFU} / \mathrm{gram}$ soil MG1655-IPTG. Headspace gas was measured using TD-GC-MS following a 48-hour incubation at $22^{\circ} \mathrm{C}$. Samples with IPTG produced significantly more $\mathrm{CH}_{3} \mathrm{Br}$ than samples lacking IPTG $\left({ }^{*}, \mathrm{p}=0.045\right)$. Data represent the average of three biological replicates. $p$-values were calculated using a twosided, independent $t$ test. 
Table 1. Soil properties. Values are reported as averages ( \pm 1 standard deviation) from three technical replicates. ${ }^{*} \mathrm{BDL}$, below detection limit.

\begin{tabular}{|c|c|c|c|c|c|c|c|c|}
\hline & Texture & $\mathrm{pH}$ & $\begin{array}{c}\text { Organic } \\
\text { C }\end{array}$ & Total $\mathbf{N}$ & $\begin{array}{c}\text { Bulk } \\
\text { density }\end{array}$ & $\mathrm{Cl}^{-}$ & $\mathrm{Br}^{-}$ & $\boldsymbol{F}^{-}$ \\
\hline & & & $(\%)$ & $(\%)$ & gram $/ \mathrm{cm}^{3}$ & ppm & ppm & ppm \\
\hline$A(0-10 \mathrm{~cm})$ & $\begin{array}{l}\text { Sandy } \\
\text { loam }\end{array}$ & 7.0 & 4.43 & 0.20 & $1.34( \pm 0.09)$ & $16.2( \pm 0.6)$ & $1.8( \pm 0.2)$ & $\mathrm{BDL}^{*}$ \\
\hline$B(10-58 \mathrm{~cm})$ & $\begin{array}{l}\text { Loamy } \\
\text { sand }\end{array}$ & 6.8 & 0.40 & $\mathrm{BDL}^{*}$ & $1.87( \pm 0.09)$ & $8.6( \pm 0.9)$ & $0.9( \pm 0.6)$ & $\mathrm{BDL}^{*}$ \\
\hline
\end{tabular}

